\title{
The effects of leaching from alkaline red mud on soil biota: modelling the conditions after the Hungarian red mud disaster
}

Márk Rékási ${ }^{\mathrm{a}}$, Viktória Feigl ${ }^{\mathrm{b}}$, Nikolett Uzinger ${ }^{\mathrm{a}}$, Katalin Gruiz ${ }^{\mathrm{b}}$, András Makóc ${ }^{\mathrm{c}}$, Attila Anton $^{\mathrm{a}}$

${ }^{a}$ Institute for Soil Sciences and Agricultural Chemistry, Centre for Agricultural Research, Hungarian Academy of Sciences, H-1022, Budapest, Herman Ottó Str. 15, Hungary.

b Department of Applied Biotechnology and Food Science, Budapest University of Technology and Economics, H-1111, Budapest, Szent Gellért square 4., Hungary

${ }^{c}$ Department of Crop Production and Soil Science University of Pannonia Georgikon Faculty, H-8360 Keszthely, Festetics Str. 7, Hungary

\section{Acknowledgement}

This is an Author's Original Manuscript of an article whose final and definitive form, the Version of Record, has been published in the Chemistry and Ecology, published online: 16 July 2013 [copyright Taylor \& Francis], available online at: http://www.tandfonline.com/[10.1080/02757540.2013.817568].

\begin{abstract}
A soil column experiment was set up to investigate the effect of red mud from Ajka (Hungary) on a typical soil profile from the concerned area. The chemical changes caused by the leachate of the red mud and the effects of these changes on living organisms were assessed. Ecotoxicological tests with Vibrio fischeri, Sinapis alba and Folsomia candida were performed and the number of aerobic heterotrophic microorganisms was determined. The total, plant available, exchangeable and water soluble fractions of $\mathrm{Na}, \mathrm{Mo}, \mathrm{Cu}$, and $\mathrm{Cr}$ increased in the soil mostly due to their leaching from the red mud layer and partly to the increase of the $\mathrm{pH}$ and DOC concentration. The chemical changes had significant effects on the test organisms only in the $0-30 \mathrm{~cm}$ soil layer except for $F$. candida that had a lower survival rate also in the $30-50 \mathrm{~cm}$ soil layer. There were no severe toxic effects detected on the test organisms. Furthermore in case of the aerobic heterotrophic cell number and $S$. alba germination a stimulating effect was revealed. However, the red mud itself was toxic, therefore the performed ecotoxicology tests have justified the removal of red mud from the soil surface after the disaster.
\end{abstract}

Keywords: element fractions, leaching, ecotoxicology test, bauxite residue, heavy metals

*Corresponding author. Email: uzinger.nikolett@agrar.mta.hu 


\section{Introduction}

On the $4^{\text {th }}$ October 2010 the red mud impoundment wall at the Ajka Timföldgyár Ltd. aluminium factory collapsed [1]. This was the most serious industrial accident ever recorded involving the release of red mud at such a scale. A total of $700,000 \mathrm{~m}^{3}$ highly alkaline $(\sim \mathrm{pH}$ 13) material flowed into the Torna creek and the surrounding area, covering more than 800 ha including settlements (Kolontár, Devecser, Somlóvásárhely). The average thickness of the red mud layer on soil surface was $5-10 \mathrm{~cm}(\min .3 \mathrm{~cm}$, max. $45 \mathrm{~cm})$. The removal of the red mud layer from the soil surface had started a few weeks after the disaster but in some areas the red mud covered the soil for more than 3 months.

Red mud is the by-product of the Bayer process in which aluminium is produced from bauxite by digestion at high temperature with concentrated caustic soda $(\mathrm{NaOH})$. The main components of red mud are $\mathrm{Fe}, \mathrm{Al}$ and $\mathrm{Si}$. Based on 18 red mud samples, Snars and Gilkes [2] found that the average $\mathrm{Fe}_{2} \mathrm{O}_{3}, \mathrm{Al}_{2} \mathrm{O}_{3}$ and $\mathrm{SiO}_{3}$ content of the red mud was 33, 20 and $16 \%$, respectively. The environmentally harmful properties of red mud are its caustic nature, high sodium and salt content, heavy metal content and radioactivity [3]. From these parameters the caustic alkalinity may pose a risk to any living organism and from the plant physiology point of view the salt content can be another stressful issue $[4 ; 5]$.

A laboratory soil column experiment was set up to study the potential effects of the disaster. We modelled the scenario after the drainage of the liquid phase of the red mud slurry having the red mud already settled as sediment on the soil surface. This layer could hinder the gas exchange of the soil, creating anoxic conditions. This red mud layer could possibly unfavourably modify the soil water balance and the rainfall would leach dissolved components into the soil.

A soil column was set up from the typical soil profile of the concerned area. These soils are heterogeneous, because of the diversity of the parent material, and due to the age, geomorphology and hydrogeology of the soils. The soil profiles are layered in the deeper horizons as a result of the Fluvisol characteristics. The profiles are carbonated from the surface; the $\mathrm{pH}$ is neutral or slightly alkaline. The groundwater level is within $1 \mathrm{~m}$. At the time of the disaster the soils were saturated due to the abundant precipitation in the area [6].

The leaching of the elements studied in this experiment was partly discussed in a previous work [7]. Anton et al. [7] showed that the concentration of potentially toxic elements considering the 6/2009 common order of the Ministry of Environment and Water, Ministry of Health and Ministry of Rural Development [8] remained below the contamination level in the soil and the only threatening factor was the increase of the Na concentration that may pose soil salinization risk in the area.

However, the results of the chemical analysis cannot be necessarily correlated with the possible hazard of a contamination posed to a certain area and biota. To provide a realistic risk assessment of a contamination, ecotoxicological assays should be conducted in addition to the measurement of chemical parameters. Test methods ensuring direct contact between the soil and the test organism can better characterise real situations in the soil than chemical analysis or biological testing of soil extracts. The ecotoxicological assays should use different organisms, which better represent the natural environment $[9 ; 10]$.

Numerous works have been published about the relationship between red mud and its effects on different organisms and element bioaccessibility. Some of these works investigated the red mud as an ameliorant of contaminated soil $[11 ; 12 ; 10 ; 13]$, or studied the effect of the treated red mud leachate on living organisms [4], or presented the results of revegetation experiments on bauxite residue disposal areas [14]. In the case of the Ajka disaster the soil was uncontaminated and the red mud was untreated and had high $\mathrm{pH}$ so that it was anticipated that its alkaline leachate would have adverse effects on soil biota. This question is important 
not only in respect of the disaster but also in respect of the applied red mud storage method. Lagooning is one of the most widespread red mud storage methods. This storage method was used by the Ajka Timföldgyár Ltd at the time of the disaster. The risk of such a storage method is not limited only to the possibility of such a disaster but also to the liquor leakage through the sealant of the lagoon that may contaminate groundwater and soil [15]. This contamination source may have similar effects like the percolation water leaching through the red mud layer into the soil as simulated in this experiment. For this reason this study aims to contribute also to the risk assessment of this bauxite residue storage method.

The principal aim of the present work was to investigate the effect of the changes of four element fractions (total, plant available, exchangeable and water soluble), $\mathrm{pH}$ and DOC on living organisms. The data on the response of test organisms to the red mud contamination may modulate the results based simply on soil chemical properties found by Anton et al. [7]. The two main questions are (i) if the changes in the soil induced by the leaching from red mud layer would cause toxicity to the test organisms and (ii) whether the assumed effects could be connected directly to some modified soil parameters.

\section{Materials and methods}

\subsection{Experimental setup}

The model soil profile for the experiment was collected from the uncontaminated arable land soil profile $(0-100 \mathrm{~cm})$ in Kolontár (Latitude: $47^{\circ} 5^{\prime} 55.60^{\prime \prime} \mathrm{N}$, Longitude: $17^{\circ} 28^{\prime} 12.96 " \mathrm{E}$, elevation: $182 \mathrm{~m}$ ). Four layers were identified according to texture and colour:

1. $0-30 \mathrm{~cm}$ : sandy loam with gravel

2. $30-50 \mathrm{~cm}$ : sand with higher gravel content

3. $50-80 \mathrm{~cm}$ : sand with gravel and a coherent gravel layer at $60 \mathrm{~cm}$

4. $80-100 \mathrm{~cm}$ : sand with gravel

The chemical properties of the soil layers are shown in Table 1.

The model soil was dried and the volume of gravel was measured. The soils of each layer were homogenised, then filled into $100 \mathrm{~cm}$ long PVC tubes (diameter: $15 \mathrm{~cm}$ ) according to the original sequence of the layers. The bottom of the columns was closed with a polyethylene textile. The soil was filled into the column from the top and compacted. The bulk density of each soil layer was adjusted to the same value: after the addition of each $5 \mathrm{~cm}$ soil layer the weight of the column was measured. Before red mud application the soils were saturated to the maximum water holding capacity from the bottom of the column.

The red mud used for the experiment was collected from the disaster area on $29^{\text {th }}$ October, 25 days after the collapse of the dam. At that time the $\mathrm{pH}$ of the red mud had decreased from its original value $(\sim \mathrm{pH} 13)$ to 10.2 . The original $\mathrm{pH}$ was above the limit value for qualification as hazardous waste (11.5) according to the Basel Convention [16]. The red mud suspension could be thus classified as hazardous material. The element composition and element fractions of red mud are shown in Table 2. The total concentration of Mo was below the water soluble. This discrepancy is due to the determination method of total fraction. The acidic extraction may underestimate the concentrations of elements that can be present in the soil in anionic form.

The experiment modelled the effect of precipitation on a $10 \mathrm{~cm}$ thick red mud layer that was placed on the top of the soil column, which was the average thickness of the red mud in the disaster area and this is equivalent to about $1900 \mathrm{t} \mathrm{red} \mathrm{mud/ha.} \mathrm{The} \mathrm{water} \mathrm{content} \mathrm{of} \mathrm{the}$ red mud was set to $38 \%$ in accordance with the value measured at the time of sampling. The time that elapsed after the top of the column was covered with red mud was taken as the treatment. Four periods were investigated: 0, 30, 60 and 120 days, each in three replications. 
At the end of the given time period the columns were divided into four sections according to the soil layers. Further analysis was performed on these separated soil layers.

During the 120 days of the experiment the columns were irrigated according to the precipitation observed in the disaster area. The total amount of irrigation water was $51 \mathrm{~mm}$ $(901 \mathrm{ml})$ at the end of the 30 day period, $132.8 \mathrm{~mm}(2346 \mathrm{ml})$ after 60 days and $181.8 \mathrm{~mm}$ $(3212 \mathrm{ml})$ after 120 days. Thus, the cumulative amount of water added in the experiment $(181.1 \mathrm{~mm})$ was equivalent to about one third of the annual average precipitation in Hungary. The temperature was set to $17^{\circ} \mathrm{C}$.

\subsection{Chemical analysis}

The soil samples were dried before chemical analyses. The soil $\mathrm{pH}$ was measured according to the Hungarian Standard [17] in 1:2.5 soil:water and soil:1 $\mathrm{M} \mathrm{KCl}$ suspensions after standing for 12 hours.

The soil organic matter content was measured by oxidation with $\mathrm{K}_{2} \mathrm{Cr}_{2} \mathrm{O}_{7}$ according to the method of Tyurin [18]. Dissolved organic carbon (DOC) was measured by extraction with $0.01 \mathrm{M} \mathrm{CaCl}_{2}$ in a 1:10 soil:solution ratio for 2 hours [19]. DOC was measured using a TOC/TN analyser (Tekmar Dohrmann Apollo 9000) involving combustion $\left(680^{\circ} \mathrm{C}\right)$ with a platinum catalyst. The CEC values of the soils were measured by the modified method of Mehlich [20, 21].

The total element concentrations were determined with the ICP-AES method after microwave teflon bomb digestion with $\mathrm{cc} . \mathrm{HNO}_{3}+\mathrm{HCl}$ [22]. The water-soluble element contents were measured in a 1:10 soil:water extract [22]. The plant available element concentrations were measured in $0.5 \mathrm{M} \mathrm{NH}_{4}$-acetate + $0.02 \mathrm{M}$ EDTA extract according to Lakanen and Erviö [23,22]. Exchangeable element fraction was determined by $\mathrm{NH}_{4}$-acetate ( $\mathrm{pH}$ 4.5) extraction [24]. In each fraction the following elements were analysed: As, Cd, Cr, $\mathrm{Cu}, \mathrm{Mo}, \mathrm{Na}, \mathrm{Pb}, \mathrm{Zn}$.

The concentrations were determined by means of inductively coupled plasma-atomic emission spectrometry (ICP-AES) (Jobin-Yvon Ultima 2 sequential instrument), using Merck calibration standards and following the manufacturer's instructions. In each measurement session the extract of a standard soil sample was also analysed as a control. The calibration curves were determined after every $12^{\text {th }}$ sample.

\subsection{Microbiological and ecotoxicology tests}

All microbiological and ecotoxicological assays were performed in three replications. The aerobic heterotrophic colony forming unit's number was determined in wet soil samples. For the other ecotoxicological tests the soil samples were dried, ground and sieved through a 2 $\mathrm{mm}$ sieve. The artificial OECD soil (content: $70 \%$ sand, $20 \%$ clay, $10 \%$ peat; OECD Guideline 207, [25]) was used as uncontaminated control for the Folsomia candida mortality test and the Sinapis alba root and shoot growth inhibition test.

Aerobic heterothrophic colony forming units. The soil microbial biomass and number can be used to assess soil quality and are relatively easy to determine using rutine methods such as plate count tests [26]. Soil suspension in different concentrations is inoculated into an appropriate media ensuring that after the incubation period one colony is formed from one living cell. The colonies can be counted. The method was described by Lorch et al. [27]. The number of colonies is given as the living cell number in $1 \mathrm{~g}$ soil.

Vibrio fischeri luminescence inhibition test. Vibrio fischeri is a marine bacterium that emits light under favourable conditions. In the presence of toxic substances the luminescence is inhibited [28]. The method was developed to direct contact with soil modifying the US EPA 
Microtox ${ }^{\circledR}$ for aqueous systems standard method and was performed as described by Leitgib et al. [29]. The toxicity was characterised by ED50 values (dose producing 50\% luminescence inhibition) calculated from the dose-response curve. A laboratory standard soil (brown forest soil) was used as a control because the test with OECD soil had adverse effect on the test organism.

Sinapis alba root and shoot growth inhibition test. In the presence of toxic substances the germination rate, the growth of root and shoot of Sinapis alba (white mustard) plants are inhibited [30]. The test was performed as described by Leitgib et al. [29]. The data evaluation was based on the root and shoot length in $\mathrm{mm}$ units after 3 days of incubation. The growth inhibition was assessed by any noted length changes of mean root and shoot length, relative to the control: $\mathrm{I}(\%)=(\mathrm{C}-\mathrm{L}) / \mathrm{C} \times 100$, where $\mathrm{I}$, inhibition \%; C, length of shoot or root in the control (OECD soil); L, length of shoot or root in the sample. Before the test the germination potential of the seeds was examined at $25 \pm 1^{\circ} \mathrm{C}$ in darkness, and germination over $90 \%$ guaranteed the proper feasibility of the test.

Folsomia candida (Collembola) mortality test. Folsomia candida is a soil living hexapod from the class of springtails (Collembola) which is sensitive to toxic substances [21]. In the acute test the number of animals survived after 1 week contact time is counted. The method was developed to direct contact with soil based on the ISO procedure [32] and was performed as described by Leitgib et al. [29]. The mortality was calculated: $\mathrm{I}(\%)=(\mathrm{C}-\mathrm{S}) / \mathrm{C} \times 100$, where $\mathrm{I}$, inhibition \%; $\mathrm{C}$, number of animals survived in the control (OECD soil); S, number of animals survived in the sample. The animals were 14 days old from a synchronized culture.

\subsection{Statistical analysis}

The data were analysed for treatment effects using one-way analysis of variance (ANOVA), on the main treatments (time period, different layers). Significant differences between the treatment means were calculated by the LSD (least significant difference) test at $\mathrm{p}<0.05$. In the correlation analysis the asterisks, $*, * *$ and $* * *$ indicate significance at $\mathrm{p}<$ $0.05,0.01$ and 0.001 , respectively. Statistica v.9 (StatSoft Inc.) software was used for all the statistical evaluations.

\section{Results and discussion}

\subsection{Soil properties}

The discussion of the results is limited to the parameters that showed significant changes during the 120 days of the experiment (Table 3 ).

The plant available $\mathrm{Cu}$ and $\mathrm{Pb}$ concentration increased in the total soil profile. The water soluble and plant available $\mathrm{Na}$ concentrations changed up to the depth of 80 and $50 \mathrm{~cm}$, respectively. The total $\mathrm{Mo}$ and $\mathrm{Na}$, the plant available $\mathrm{Mo}$, the exchangeable $\mathrm{Na}$ and the water soluble $\mathrm{Cu}$ and $\mathrm{Cr}$ concentrations increased only in the top soil layer. These results show that the red mud layer affected the most the $\mathrm{Na}$ content of the soil layer since it increased significantly in each fraction. The plant available and exchangeable Na concentration is almost identical showing the high mobility of this element that caused its high volume leaching from the red mud layer.

The soil $\mathrm{pH}$ changed significantly up to the $100 \mathrm{~cm}$ depth already after 30 days. In the top soil layer the neutral $\mathrm{pH}$ (6.8) became slightly alkaline (8.0) after 120 days. The concentration of DOC followed the $\mathrm{pH}$ changes with a delay: the increment became significant only after 120 days. The DOC concentration increased function of soil $\mathrm{pH}$ but this connection was not significant (Table 4). 
The concentration of differently soluble elements increased as a result of the red mud treatment. These concentration changes in the soil theoretically can be traced back to three main causes: leaching from the red mud layer, $\mathrm{pH}$ change and increase in DOC concentration. Generally the higher $\mathrm{pH}$ values result lower element solubility but the increased DOC concentration induced by higher $\mathrm{pH}$ may cause an opposite effect [33]. Furthermore there are elements present in the soil in anionic forms which remain soluble at higher $\mathrm{pH}$ values [34, 35]. To investigate this question a correlation analysis was made between the soil properties confined to the top soil layer where each parameter changed (Table 4).

The results show that characteristically almost each parameter correlates positively with the others in the $0-30 \mathrm{~cm}$ soil layer. The DOC correlates only with the plant available $\mathrm{Cu}$ concentration that can be the result of the strong affinity of this element to organic substances [36]. The $\mathrm{pH}$ correlates with each element except the water soluble $\mathrm{Cr}$ and $\mathrm{Na}$. From the discussed elements only the Mo solubility could be increased directly by the $\mathrm{pH}$ changes since this element can be mobile at alkali $\mathrm{pH}$ in an anionic form [34]. In this experiment the water soluble Mo concentration was under the detection limit but the plant available Mo indicates increased Mo mobility in the top soil layer. In the case of other elements the positive correlation with $\mathrm{pH}$ is significant because of the parallel changes between element concentrations and soil $\mathrm{pH}$ during the time of the experiment. Thus these concentration changes are connected to the leaching and in case of total $\mathrm{Na}$ and $\mathrm{Mo}$ to the downward movement of red mud particles from red mud layer [7]. Similarly the leaching can explain the correlation between the different element fractions. Based on the above only the plant available $\mathrm{Cu}$ and water soluble Mo concentration changes may have been influenced to a greater extent by the changes of soil $\mathrm{pH}$ and DOC concentrations. The most important factor in concentration changes was the leaching from red mud.

All of these changes are officially not harmful since the element concentrations remained below the limit values laid down in the relevant soil quality standards [8]. These results are favourable for the remediation and recultivation of the area. However, the elevated $\mathrm{Na}$ concentrations in the soil could pose soil salinization risk [7].

\subsection{Microbiology and Ecotoxicology}

The applied test organisms represent different levels of the food chain. In general, the results show that the red mud contamination of the soil did not cause any serious inhibition on test organisms. In fact the opposite effect could be detected by the increment of aerobic heterotrophic cell number and Sinapis alba root and shoot growth. The Folsomia candida mortality test was the only that showed the potential toxicity of red mud treated soil. Only the results of Vibrio fischeri test did not show any significant change during the time of the experiment. The significant effects were limited to the top soil layer. The only exception was Folsomia candida mortality test that resulted changes also in the $30-50 \mathrm{~cm}$ layer (Table 5).

Regarding the correlations between the results of toxicology tests and soil properties it is difficult to establish direct relationships with one soil property and toxicity because of the inter-correlation of soil parameters (Table 6). However, based on literature data some assumptions can be drawn.

The aerobic heterotrophic living cell number increased significantly for up to 60 days then after 120 days its value decreased to the 0 day level. Despite its significance this fluctuation had not a high weight: the cell number value remained at the same magnitude of order. The increment in cell number can be the result of the adaptation of microbes to the changes of the environment [37]. The decline of cell number in the last sampling time may be due to the lack of water supply: after the $76^{\text {th }}$ day only $10 \mathrm{~mm}$ water was irrigated to the top of the column. In 
the $30-50 \mathrm{~cm}$ layer the tendency of the changes are similar but the differences are not significant.

These results are partially coherent with the findings of Garau et al. [11] whose results showed that the red mud treatment on arsenic contaminated soil increased the heterotrophic bacteria number, reducing the mobility of As and releasing $\mathrm{C}, \mathrm{N}$ and $\mathrm{P}$ from soil organic matter after increasing its solubility with the elevation of the $\mathrm{pH}$. Similarly Castaldi et al. [12] found that red mud application had a significant positive effect on bacterial number in $\mathrm{Pb}, \mathrm{Zn}$ and $\mathrm{Cd}$ contaminated acidic soil. Lombi et al. [10] observed also increasing microbial biomass volume on contaminated soil after red mud application. In these trials the increment in biological activity was connected to the reduced mobility of the soil contaminants. In the present experiment the soil was not toxic thus the cell number increment can be attributed to the increment of DOC concentration and probably of the available nutrients [38]. In the $0-30$ $\mathrm{cm}$ soil layer the aerobic heterotrophic cell number correlated significantly only with the DOC amongst the investigated parameters but this connection was negative (Table 6). Since the soil respiration and DOC concentration is positively correlated [39], it leads to the assumption that the decreasing cell number has slowed down the decomposition of DOC resulting an increment in the DOC concentration initiated by the higher $\mathrm{pH}$. Considering the total soil column the DOC was in positive significant correlation $\left(\mathrm{r}=0.52^{* *}\right)$ with aerobic heterotrophic living cell number. Thus the negative changes can be related to the decrease in soil water content.

In the $0-30 \mathrm{~cm}$ soil layer the leaching from red mud had a positive effect on both Sinapis alba root and shoot growth. The average root and shoot length increased by $36 \%$ and $13 \%$ respectively after 120 days compared to the control OECD soil. Lombi et al. [10] reported also that the red mud had positive effect on plants (growth, biomass, yield) due to the reduction of the toxicity of soil contamination. In contempt of these results the red mud in itself almost totally inhibited the Sinapis alba germination (the average shoot and root length was below $1 \mathrm{~mm}$ ) that result verifies the findings of Courtney and Mullen [14].

According to the results presented in Table 6 almost each soil parameter had significant positive effect on root length. In the case of shoot the results are similar but the correlation was significant only in the case of plant available $\mathrm{Na}$, exchangeable $\mathrm{Na}$ and water soluble $\mathrm{Cr}$ and $\mathrm{Cu}$. Because of the inter-correlation of soil properties it is difficult to establish direct relationships between toxicity and soil chemical changes. However, Fargasova and Molnarova [40] reported also stimulating effects of low $(0.3 \mathrm{mg} / \mathrm{kg}) \mathrm{Cr}$ concentration waste water on Sinapis alba shoot dry mass (after 10 days growth). Thus, the observed positive effect in this experiment can be explained by the increment in microelement concentration in soil. Based on the correlation coefficients in Table 6 the root growth was more determined by the investigated soil parameters than by the shoot elongation.

Dalzell et al. [41] demonstrated that Vibrio fischeri test is a sensitive bioassay for a wide range of toxic substances. In this experiment the results of luminescence inhibition test (ED50 value) did not change significantly after the red mud treatment in any soil layer. Brunori et al. [4] performed this test in leachate of seawater treated, neutralised red mud and found that this ecotoxicological test did not show any inhibition. In our case the untreated alkaline red mud in itself was toxic to this testorganism: only $3.1 \mathrm{mg}$ was enough to reach the $50 \%$ light extinction.

The Folsomia candida mortality was the only test that showed significant changes apart from the top soil layer. The I \% value significantly increased in the $0-30$ and $30-50 \mathrm{~cm}$ soil layer after 120 days. But this increased mortality was only $7 \%$ in the top soil layer and 13.3 $\%$ in the $30-50 \mathrm{~cm}$ layer. The red mud in itself did not cause extreme high mortality (11.7 $\%)$ either. 
Similarly to the case of Sinapis alba root germination the Folsomia survival correlated with almost each soil parameter that showed significant change caused by the contaminant leaching from red mud. Based on the correlation coefficients of Table 6 the plant available $\mathrm{Na}$ and the DOC were primarily connected to Folsomia survival both in the $0-30$ and $30-50 \mathrm{~cm}$ soil layer. The effect of DOC concentration probably manifests via its influence of metal solubility and not directly [42]. Literature data about the direct effect of $\mathrm{Na}$ on Folsomia candida mortality according to our current knowledge can not be found but Owojori et al. [43] reported that salinity had not affected significantly the survival of Folsomia candida. According to literature data the $\mathrm{Cr}$ (III) does not have any negative effect on Folsomia survival. Lock and Janssen [44] found that mortality was lower than $10 \%$ even at $1000 \mathrm{mg}$ $\mathrm{Cr} / \mathrm{kg}$ soil dry weight. However, in the present experiment the red mud might contain $\mathrm{Cr}(\mathrm{VI})$ that could cause toxicity in the observed concentration also [7]. Based on the results of Sandifer and Hopkin [45] it can be assumed that the lead content of the soil did not cause any adverse effect on Folsomia survival at the $\mathrm{pH}$ value of the investigated soil. The $\mathrm{pH}$ itself may have an effect on the survival of the individuals but this connection is not revealed in detail [46]. Pedersen et al. [47] investigated copper toxicity on Folsomia candida on different pH values. Even on acidic $\mathrm{pH}$ and total $\mathrm{Cu}$ concentration one order of magnitude higher than in the soil after red mud disaster, the mortality of adult Collembola was as high as in the present experiment. They qualified this mortality rate as the $\mathrm{Cu}$ had no effect on Folsomia.

Vijver et al. [48] suggested that in case of collembolans the pollutant uptake is more directly related to the soil solid phase than the soil solution. The correlation coefficients in Table 6 did not support these results since there are no visible differences in the values of coefficients in function of the differently soluble fractions of the elements. However, the element concentrations in this experiment might be too low to see this phenomenon. Furthermore our results show that a single soil parameter cannot cause alone the negative effect in the Folsomia experiment but it must be the combination of the changes in soil properties that affected the Folsomia survival. Or the observed effects may be attributable to contaminants not considered in this study.

The results of toxicity tests showed that the leaching from the red mud caused statistically significant adverse effect only on Folsomia candida but based on literature data this change can be quoted as insignificant toxicity. The leaching from red mud promoted increment in aerobic heterotrophic cell number and the germination of Sinapis alba. From the present experiment the direct effect of different soil properties on the test organisms could not be distinguished. The red mud in itself was toxic to the test organisms (Table 5). These diverse results obtained by the test organisms indicate the necessity of using different ecotoxicological tests as suggested by Lombi et al. [10] and Gruiz et al. [9].

\section{Conclusions}

Our leaching experiment modelled the effect of the red mud layer on soil properties after the red mud disaster in Hungary.

The leaching from red mud layer caused increments in the total, plant available, exchangeable and water soluble fractions of $\mathrm{Na}, \mathrm{Mo}, \mathrm{Cu}$, and $\mathrm{Cr}$. Furthermore, it increased the $\mathrm{pH}$ and DOC concentration. These changes were mostly limited to the $0-30 \mathrm{~cm}$ soil layer. The concentrations of the elements remained under the limit values of the soil quality standards currently in force in Hungary.

The red mud leachate induced chemical changes in the soil did not cause any severe toxic effects on the test organisms and in case of the aerobic heterotrophic cell number and Sinapis alba germination even a stimulating effect was revealed. Thus the $10 \mathrm{~cm}$ thick red mud layer on the soil surface did not cause any significant negative effects on test organisms in the $1 \mathrm{~m}$ 
deep soil profile during 120 days. However, the red mud itself was toxic to the test organisms. Thus, the removal of red mud from soil surface after the disaster was justified by these ecotoxicology tests.

\section{Acknowledgement}

The authors would like to thank Anett Szabó, Bálint Papp (Budapest University of Technology and Economics); Hilda Hernádi, Gábor Széplábi (University of Pannonia) and Tibor Szili-Kovács (Institute for Soil Sciences and Agricultural Chemistry) for their valuable assistance. This work was supported by National Innovation Office (SOILUTIL, TECH-09A4-2009-0129), the scholarship of the TÁMOP 4.2.4.A-1 project financed by the Hungarian State and the European Union, co-financed by the European Social Fund and by the János Bolyai Research Scholarship of the Hungarian Academy of Sciences.

\section{References}

[1] J. Szépvölgyi, Some thoughts on the red mud spill in Ajka. (In Hungarian) Magyar Tudomány. 12 (2010), pp. 1467-1472.

[2] K. Snars and R.J. Gilkes, Evaluation of bauxite residues (red muds) of different origins for environmental applications. Appl. Clay Sci. 46 (2009), pp. 13-20.

[3] C. Klauber, M. Gräfe and G. Power, Bauxite residue issues: II. options for residue utilization. Hydrometallurgy. 108 (2011), pp. 11-32.

[4] C. Brunori, C. Cremisini, P. Massanisso, V. Pinto and L. Torricelli, Reuse of a treated red mud bauxite waste: studies on environmental compatibility. J. of Hazard. Mater. 117 (2005), pp. 55-63.

[5] S. Ruyters, J. Mertens, E. Vassilieva, B. Dehandschutter, A. Poffin and E. Smolders, Red mud accident in Ajka (Hungary): plant toxicity and trace metal bioavailability in red mud contaminated soil. Environ. Sci. and Tech. 45 (2011), pp. 1616-1622.

[6] A. Anton, General aspects for the planning and evaluation of soil remediation in the red mud contaminated area. (In Hungarian) (2010) RISSAC report. http://mta-taki.hu/files/story/2010/10/15/509/mta_taki_talajremediacios_javaslatai_pdf 17089.pdf. Accessed 15 October 2010.

[7] A. Anton, M. Rékási, N. Uzinger, G. Széplábi and A. Makó, Modelling the potential effects of the Hungarian red mud disaster on soil properties. Water Air and Soil Pollut. 223 (2012), pp. 5175-5188.

[8] 6/2009. (IV. 14.) KvVM-EüM-FVM common order about the standard limits and measurement of contamination for the protection of underground water and geological medium. (In Hungarian) Magyar Közlöny, 51, pp. 14398-14414.

[9] K. Gruiz, M. Molnár and V. Feigl, Measuring adverse effect of contaminated soil using interactive and dynamic methods. Land Contamination and Reclamation. 17 (2009), pp. 443-459.

[10] E. Lombi, F-J. Zhao, G. Wieshammer, G. Zhang and S.P. McGrath, In situ fixation of metals in soils using bauxite residue: biological effects. Environ. Pollut. 118 (2002), pp. 445-452.

[11] G. Garau, P. Castaldi, L. Santona, P. Deiana and P. Melis, Influence of red mud, zeolite and lime on heavy metal immobilization, culturable heterotrophic microbial populations and enzyme activities in a contaminated soil. Geoderma. 142 (2007), pp. 47-57.

[12] P. Castaldi, P. Melis, M. Silvetti, P. Deiana and G. Garau, Influence of pea and wheat growth on $\mathrm{Pb}, \mathrm{Cd}$, and $\mathrm{Zn}$ mobility and soil biological status in a polluted amended soil. Geoderma. 151 (2009), pp. 241-248 
[13] Y.Z. Huanga and X.W. Hao, Effect of red mud addition on the fractionation and bioaccessibility of $\mathrm{Pb}, \mathrm{Zn}$ and As in combined contaminated soil. Chemistry and Ecology. 28 (2012), pp. 37-48.

[14] R. Courtney and G. Mullen, Use of germination and seedling performance bioassays for assessing revegetation strategies on bauxite residue. Water, Air and Soil Pollut. 197 (2009), pp. 15-22.

[15] G. Power, M. Gräfe and C. Klauber, Bauxite residue issues: I. Current management, disposal and storage practices. Hydrometallurgy. 108 (2011), pp. 33-45.

[16] 240/2005. (X. 27.) Government Order On the announcement of modifications in the control of transboundary movements of hazardous wastes and their disposal (Basle Convention). Magyar Közlöny, 2005/142. pp. 7789-7811.

[17] MSZ-08-0206/2-1978. Evaluation of some chemical properties of the soil. Laboratory tests. ( $\mathrm{pH}$ value, phenolphtalein alkalinity expressed in soda, total water soluble salt content, hydrolytic (yl value) and exchangeable acidity (y2 value). (In Hungarian) Hungarian Standard Association. Budapest.

[18] I.V. Tyurin, A new modification of the volumetric method of determining soil organic matter by means of chromic acid. Pochvovedenie. 26 (1931), pp. 36-47.

[19] I. Jászberényi, J. Loch and J. Sarkadi, Experiences with $0.01 \mathrm{M} \mathrm{CaCl}_{2}$ as an extraction reagent for use as a soil testing procedure in Hungary. Comm. Soil Sci. Plant Anal. 25 (1994), pp. 1771-1777.

[20] A. Mehlich, Determination of cation- and anion-exchange properties of soils. Soil Sci. 66 (1948), pp. 429-445.

[21] MSZ-08-0215:1978. Determination of the Cation Adsorption Capacity of the Soil. Modified Mechlich Technique. (In Hungarian) Hungarian Standard Association, Budapest.

[22] MSZ 21470-50:2006. Environmental testing of soils. Determination of total and soluble toxic element, heavy metal and chromium (VI) content. (In Hungarian) Hungarian Standard Association, Budapest.

[23] E. Lakanen and R. Erviö, A comparison of eight extractants for the determination of plant available micronutrients in soils. Acta Agr. Fenn. 123 (1971), pp. 223-232.

[24] MSZ 21420-31:2006. Characterization of wastes. Part 31: Ammonium acetate puffer extract for physical-, chemical and ecotoxicological characterisation. (In Hungarian) Hungarian Standard Association, Budapest.

[25] OECD Earthworm, acute toxicity tests. OECD-guideline for testing of chemicals no. 207. Paris, (1984).

[26] A. Benedetti and O. Dilly, Introduction. In Bloem et al. (Eds.), Mocrobial methods for assessing soil quality. CABI Publishing, Wallingford, 2006, pp. 3-15.

[27] H.J. Lorch, G. Benckieser and J.C.G. Ottow, Basic methods for counting microorganisms in soil and water. In: K. Alef, P. Nannipieri (Eds.), Methods in Applied Soil Microbiology and Biochemistry. Academic Press, London, 1995, pp. 146-161.

[28] A.A. Bulich and D.L. Isenberg, Use of the luminescent bacterial system for the rapid assessment of aquatic toxicity. ISA Trans. 20 (1981), pp. 29-33

[29] L. Leitgib, J. Kálmán and K. Gruiz, Comparison of bioassays by testing whole soil and their water extract from contaminated sites. Chemosphere. 66 (2007), pp. 428-434,

[30] OECD Terrestial plant test: Seedling emergence and seedling growth test. OECD guideline for testing of chemicals no. 208. Paris,(2006).

[31] J.A. Wiles and P.H. Krogh, Tests with the Collembolans Isotoma viridis, Folsomia candida and Folsomia fimetaria. In H. Lokke, C.A.M. van Gestel (Eds.), Handbook of soil invertebrate toxicity tests. John Wiley \& Sons, Chichester, 1998, pp. 131-156. 
[32] ISO, Soil Quality-Effects of Soil Pollutants on Collembola: Determination of the Inhibitionof Reproduction. ISO/TC 190/SC4/WG2, N26. (1991).

[33] M. McBride, S. Sauvé and W. Hendershot, Solubility control of $\mathrm{Cu}, \mathrm{Zn}, \mathrm{Cd}$ and $\mathrm{Pb}$ in contaminated soils. Eur. J. of Soil Sci. 48 (1997), pp. 337-346.

[33] D. Shaw, Mobility of arsenic in saturated, laboratory test sediments under varying $p H$ conditions. Eng. Geology. 85 (2006), pp. 158-164.

[34] T. Németh and I. Kádár, Leaching of microelement contaminants: a long-term field study. Z. Naturforsch. 60c (2005), pp. 260-264.

[36] D.C. Adriano, Trace Elements in the Terrestrial Environments. Springer-Verlag, New York, 1986, pp. 499-546.

[37] P.C. Brooks, S.P. McGrath, D.A. Klein and E.T. Elliot, Effects of heavy metals on microbial activity and biomass in field soils treated with sewage sludge. In Perry et al. (Eds.), Environmental Contamination. Publishers CEP Ltd, Edinburgh, 1984, pp. 574583.

[38] H.K. Jokinen, O. Kiikkilä and H. Fritze, Exploring the mechanisms behind elevated microbial activity after wood ash application. Soil Biol. and Biochem. 38 (2006), pp. 2285-2291.

[39] B. Marschner and A.D. Noble, Chemical and biological processes leading to the neutralisation of acidity in soil incubated with litter materials. Soil Biol. and Biochem. 32 (2000), pp. 805-813.

[40] A. Fargasova and M. Molnarova, Assessment of $\mathrm{Cr}$ and Ni phytotoxicity from cutlerywashing waste-waters using biomass and chlorophyll production tests on mustard Sinapis alba L. seedlings. Environ. Sci. Pollut. Res. 17 (2010), pp. 187-194.

[41] D.J.B. Dalzell, S. Alte, E. Aspichueta, A. de la Sota, J. Etxebarria, M. Gutierrez, C.C. Hoffmann, D. Sales, U. Obst and N. Christofi, A comparison of five rapid direct toxicity assessment methods to determine toxicity of pollutants to activated sludge. Chemosphere. 47 (2002), pp. 535-545.

[42] D. M. Di Toro, H.E. Allen, H. Bergman, J.S. Meyer, P.R. Paquin and C.S. Santore, Biotic ligand model of the acute toxicity of metals: 1. Technical basis. Environ. Toxicol. Chem. 20 (2001), pp. 2383- 2396.

[43] O.J. Owojori, A.J. Reinecke, P. Voua-Otomo and S.A. Reinecke, Comparative study of the effects of salinity on life-cycle parameters of four soil-dwelling species (Folsomiacandida, Enchytraeus doerjesi, Eisenia fetida and Aporrectodea caliginosa). Pedobiologia. 52 (2009), pp. 351-360.

[44] K. Lock and C.R. Janssen, Ecotoxicity of Chromium (III) to Eisenia fetida, Enchytraeus albidus, and Folsomia candida. Ecotoxicol. and Environ. Safety. 51, (2002), 203-205.

[45] R.D. Sandifer and S.P. Hopkin, Effects of $\mathrm{pH}$ on the toxicity of cadmium, copper, lead and zinc to Folsomia candida Willem, 1902 (Collembola) in a standard laboratory test system. Chemosphere. 33 (1996), pp. 2475-2486.

[46] T. Crommentuijn, A. Doornekamp and C.A.M. Van Gestel, Bioavailability and ecological effects of cadmium on Folsomia candida (Willem) in an artificial soil substrate as influenced by $\mathrm{pH}$ and organic matter. Appl. Soil Ecology. 5 (1997), pp. 261-271.

[47] M.B. Pedersen, E.J.M. Temminghoff, M.P.J.C. Marinussen, E. Elmegaard and C. A. M. vanGestel, Copper accumulation and fitness of Folsomia candida Willem in a copper contaminated sandy soil as affected by $\mathrm{pH}$ and soil moisture. Appl. Soil Ecol. 6 (1997), pp. 135-146.

[48] M. Vijver, T. Jager, L. Posthuma and W. Peijnenburg, Impact of metal pools and soil properties on metal accumulation in Folsomia candida (Collembola). Environ. Toxicol. and Chem. 20 (2001), pp. 712-720. 
Table 1. Selected chemical properties of the soil layers in the column

\begin{tabular}{c|c|c|c|}
\hline Depth & $\begin{array}{c}\text { pH } \\
\text { (KCl) }\end{array}$ & $\begin{array}{c}\text { Organic } \\
\text { Matter \% }\end{array}$ & $\begin{array}{c}\text { CEC } \\
(\mathbf{m e q} / \mathbf{1 0 0 g})\end{array}$ \\
\hline $\mathbf{0 - 3 0} \mathbf{~ c m}$ & 6.76 & 2.17 & 9.33 \\
$\mathbf{3 0 - 5 0} \mathbf{~ c m}$ & 6.80 & 1.32 & 9.97 \\
$\mathbf{5 0 - 8 0} \mathbf{~ c m}$ & 7.20 & 0.64 & 9.63 \\
$\mathbf{8 0 - 1 0 0 ~ c m}$ & 7.92 & 0.38 & 7.27 \\
\hline
\end{tabular}

Table 2. Total (cc. $\mathrm{HNO}_{3}+\mathrm{HCl}$ soluble), plant available $\left(\mathrm{NH}_{4}\right.$-acetate + EDTA soluble) and exchangeable $\left(\mathrm{NH}_{4}\right.$-acetate soluble) water soluble element concentrations in the red mud $(\mathrm{mg} / \mathrm{kg} \mathrm{DW})$

\begin{tabular}{|c|c|c|c|c|c|c|c|c|c|c|c|c|}
\hline \multirow{2}{*}{ Fraction } & \multicolumn{12}{|c|}{ Elements } \\
\hline & Al & As & Cd & Co & $\mathrm{Cr}$ & $\mathbf{C u}$ & Mo & $\mathbf{N a}$ & $\mathbf{N i}$ & $\mathbf{P b}$ & Se & $\mathbf{Z n}$ \\
\hline Total & 51470 & 32.1 & 1.17 & 40.3 & 396 & 34.5 & 3.00 & 32918 & 193 & 117 & $<\mathrm{dl}$ & 107 \\
\hline Plant ava & 19389 & 4.32 & 0.207 & 0.89 & 1.45 & 14.0 & 0.50 & 28226 & 1.03 & 5.14 & $<\mathrm{dl}$ & 5.79 \\
\hline Exchangeable & $<\mathrm{dl}$ & $<\mathrm{dl}$ & 0.004 & 0.026 & $<\mathrm{dl}$ & $<\mathrm{dl}$ & 2.85 & 8770 & 0.08 & $<\mathrm{dl}$ & $<\mathrm{dl}$ & $<\mathrm{dl}$ \\
\hline Water Soluble & 167 & 2.52 & 0.011 & 0.158 & 1.27 & 1.63 & 5.35 & 3680 & 0.773 & 0.432 & $<\mathrm{dl}$ & 0.610 \\
\hline
\end{tabular}

$<\mathrm{dl}$ : under detection limit. The dl of Se was $0.6 \mathrm{mg} / \mathrm{kg}$ 
Table 3. Changes in the total (cc. $\mathrm{HNO}_{3}+\mathrm{HCl}$ soluble), plant available $\left(\mathrm{NH}_{4}\right.$-acetate + EDTA soluble), exchangeable $\left(\mathrm{NH}_{4}\right.$-acetate soluble), water soluble element concentrations ( $\mathrm{mg} / \mathrm{kg}$ ), $\mathrm{pH}$ and dissolved organic carbon (DOC, $\mu \mathrm{g} \mathrm{C} / \mathrm{g}$ soil) in the soil column

\begin{tabular}{|c|c|c|c|c|c|c|c|c|c|c|c|c|}
\hline \multirow{2}{*}{ Time } & \multicolumn{2}{|c|}{ Total } & \multicolumn{4}{|c|}{ Plant available } & \multirow{2}{*}{$\frac{\text { Exchangeable }}{\mathrm{Na}}$} & \multicolumn{3}{|c|}{ Water soluble } & \multirow{2}{*}{$\mathbf{p H}$} & \multirow{2}{*}{ DOC } \\
\hline & Mo & $\mathbf{N a}$ & $\mathrm{Cu}$ & Mo & $\mathbf{N a}$ & $\mathbf{P b}$ & & $\mathrm{Cr}$ & $\mathbf{C u}$ & $\mathbf{N a}$ & & \\
\hline & \multicolumn{12}{|c|}{$0-30 \mathrm{~cm}$} \\
\hline 0 day & 0.283 & 207 & 4.77 & 0.150 & 12 & 3.83 & 15 & 0.033 & 0.188 & 9 & 6.76 & 36.0 \\
\hline 30 days & 0.976 & 464 & 6.22 & 0.797 & 289 & 5.87 & 351 & 0.047 & 0.263 & 220 & 7.73 & 37.5 \\
\hline 60 days & 1.268 & 776 & 6.90 & 1.014 & 624 & 7.02 & 693 & 0.129 & 0.535 & 413 & 7.76 & 36.1 \\
\hline 120 days & 1.304 & 671 & 7.28 & 1.119 & 542 & 7.20 & 568 & 0.092 & 0.447 & 147 & 8.00 & 46.2 \\
\hline \multirow[t]{2}{*}{$\mathbf{L S D}_{\mathbf{5} \%}$} & 0.430 & 239 & 1.52 & 0.405 & 214 & 1.09 & 221 & 0.049 & 0.135 & 156 & 0.41 & 9.9 \\
\hline & \multicolumn{12}{|c|}{$30-50 \mathrm{~cm}$} \\
\hline 0 day & 0.040 & 209 & 5.55 & 0.083 & 9 & 3.03 & 13 & 0.053 & 0.226 & 14 & 6.80 & 26.7 \\
\hline 30 days & 0.253 & 152 & 5.62 & 0.115 & 14 & 4.00 & 14 & 0.029 & 0.211 & 15 & 7.62 & 29.8 \\
\hline 60 days & 0.084 & 214 & 6.42 & 0.095 & 39 & 4.60 & 35 & 0.051 & 0.172 & 27 & 7.61 & 26.0 \\
\hline 120 days & 0.096 & 138 & 8.52 & 0.075 & 40 & 5.38 & 43 & 0.025 & 0.265 & 113 & 7.45 & 40.5 \\
\hline \multirow[t]{2}{*}{$\mathbf{L S D}_{\mathbf{5} \%}$} & n.s. & n.s. & 0.91 & n.s. & 27 & 0.51 & n.s. & n.s. & n.s. & 48 & 0.29 & 10.0 \\
\hline & \multicolumn{12}{|c|}{$50-80 \mathrm{~cm}$} \\
\hline 0 day & 0.040 & 138 & 2.49 & 0.040 & 15 & 2.26 & 20 & 0.020 & 0.094 & 12 & 7.20 & 22.7 \\
\hline 30 days & 0.171 & 141 & 2.42 & 0.075 & 18 & 2.84 & 19 & 0.020 & 0.071 & 13 & 7.86 & 27.5 \\
\hline 60 days & 0.048 & 178 & 3.15 & 0.021 & 16 & 2.82 & 14 & 0.040 & 0.087 & 10 & 7.83 & 21.9 \\
\hline 120 days & 0.162 & 147 & 3.58 & 0.028 & 7 & 3.03 & 9 & 0.020 & 0.145 & 81 & 7.87 & 34.5 \\
\hline \multirow[t]{2}{*}{$\mathbf{L S D}_{\mathbf{5} \%}$} & n.s. & n.s. & 0.23 & n.s. & n.s. & 0.20 & n.s. & n.s. & n.s. & 5 & 0.17 & 8.0 \\
\hline & \multicolumn{12}{|c|}{$80-100 \mathrm{~cm}$} \\
\hline 0 day & 0.040 & 101 & 1.52 & 0.025 & 14 & 1.80 & 12 & 0.020 & 0.050 & 11 & 7.92 & 24.0 \\
\hline 30 days & 0.040 & 125 & 1.82 & 0.043 & 14 & 2.23 & 10 & 0.021 & 0.050 & 9 & 8.12 & 26.1 \\
\hline 60 days & 0.061 & 92 & 1.99 & 0.009 & 15 & 2.22 & 12 & 0.020 & 0.050 & 3 & 7.95 & 19.0 \\
\hline 120 days & 0.040 & 124 & 2.07 & 0.020 & 3 & 2.42 & 7 & 0.020 & 0.083 & 58 & 8.18 & 28.4 \\
\hline $\mathbf{L S D}_{\mathbf{5} \%}$ & n.s. & n.s. & 0.11 & n.s. & n.s. & 0.26 & n.s. & n.s. & n.s. & n.s. & 0.10 & 5.7 \\
\hline
\end{tabular}

n.s.: not significant, LSD $_{5 \%}$ : Least Significant Difference at $\mathrm{p}<0.05$ 
Table 4. Correlation coefficients (r) between soil element fractions, $\mathrm{pH}$ and DOC in the $0-30 \mathrm{~cm}$ soil layer. The significant correlations are highlighted with bold characters.

\begin{tabular}{|c|c|c|c|c|c|c|c|c|c|c|c|c|}
\hline \multirow{2}{*}{\multicolumn{2}{|c|}{ Parameters }} & \multicolumn{2}{|c|}{ Total } & \multicolumn{4}{|c|}{ Plant available } & \multirow{2}{*}{$\begin{array}{c}\text { Exchangeable } \\
\mathrm{Na}\end{array}$} & \multicolumn{3}{|c|}{ Water soluble } & \multirow{3}{*}{ pH } \\
\hline & & Mo & $\mathbf{N a}$ & $\mathbf{C u}$ & Mo & $\mathrm{Na}$ & $\mathbf{P b}$ & & $\mathrm{Cr}$ & $\mathbf{C u}$ & $\mathbf{N a}$ & \\
\hline Total & $\mathbf{N a}$ & \multicolumn{2}{|l|}{$0.869 * *$} & & & & & & & & & \\
\hline \multirow{4}{*}{$\begin{array}{c}\text { Plant } \\
\text { available }\end{array}$} & $\mathrm{Cu}$ & $0.949 * *$ & 0.738* & & & & & & & & & \\
\hline & Mo & $0.948 * *$ & $0.856 * *$ & $0.928 * *$ & & & & & & & & \\
\hline & $\mathbf{N a}$ & $0.896 * *$ & $0.995 * *$ & $0.773^{*}$ & $0.863^{* *}$ & & & & & & & \\
\hline & $\mathbf{P b}$ & $0.980 * *$ & $0.840 * *$ & $0.956 * *$ & $0.932 * *$ & $0.877 * *$ & & & & & & \\
\hline Exchangeable & $\mathbf{N a}$ & $0.889 * *$ & $0.993 * *$ & $0.758 *$ & $0.857 * *$ & $0.995 * *$ & $0.868 * *$ & & & & & \\
\hline \multirow{3}{*}{$\begin{array}{c}\text { Water } \\
\text { soluble }\end{array}$} & $\mathrm{Cr}$ & 0.699* & $0.911 * *$ & 0.549 & $0.630 *$ & $0.911 * *$ & $0.680^{*}$ & $0.910 * *$ & & & & \\
\hline & $\mathbf{C u}$ & $0.825 * *$ & $0.902 * *$ & $0.717 *$ & $0.757 *$ & $0.914 * *$ & $0.839 *$ & $0.896 * *$ & $0.852 * *$ & & & \\
\hline & $\mathbf{N a}$ & $0.679 *$ & $0.844 * *$ & 0.488 & $0.619 *$ & $0.816 * *$ & $0.623^{*}$ & $0.853 * *$ & $0.814 * *$ & $0.757 *$ & & \\
\hline \multirow{2}{*}{\multicolumn{2}{|c|}{$\begin{array}{c}\text { pH } \\
\text { DOC }\end{array}$}} & $0.808 * *$ & 0.772* & $0.769^{*}$ & $0.900 * *$ & 0.773* & $0.816 * *$ & 0.795* & 0.539 & 0.601* & 0.558 & \\
\hline & & 0.470 & 0.250 & $0.587 *$ & 0.424 & 0.316 & 0.475 & 0.262 & 0.180 & 0.156 & -0.178 & 0.300 \\
\hline
\end{tabular}

**Correlation is significant at the 0.01 level (2-tailed).; * Correlation is significant at the 0.05 level (2-tailed) 
Table 5. Results of the ecotoxicology tests in the $0-30 \mathrm{~cm}$ and $30-50 \mathrm{~cm}$ soil layer during the time of the experiment and in red mud

\begin{tabular}{l|c|c|c|c|c|}
\hline \multirow{1}{*}{ Time } & $\begin{array}{c}\text { aerobic } \\
\text { heterotrophic } \\
\text { cell number }\end{array}$ & $\begin{array}{c}\text { Vibrio Fischeri } \\
\text { ED50 }\end{array}$ & $\begin{array}{c}\text { Sinapis alba } \\
\text { root growth } \\
\text { inhibition }\end{array}$ & $\begin{array}{c}\text { Sinapis alba } \\
\text { shoot growth } \\
\text { inhibition }\end{array}$ & $\begin{array}{c}\text { Folsomia } \\
\text { candida } \\
\text { mortality }\end{array}$ \\
\cline { 2 - 6 } soil & mg cell/g & I\% & I\% & I\% \\
0 day & 10.2 & 54.6 & $\mathbf{0 - 3 0 ~ c m}$ & -44 & 0.0 \\
30 days & 13.6 & 61.7 & -69 & -41 & 0.0 \\
60 days & 15.1 & 67.9 & -119 & -68 & 4.0 \\
120 days & 8.1 & 67.8 & -142 & -64 & 7.0 \\
LSD & 4.5 & n.s. & -131 & 23 & 3.3 \\
\hline \\
0 day
\end{tabular}


Table 6. Correlation coefficients (r) between soil properties and the results of microbiological and toxicological tests in the 0 -30 and $30-50 \mathrm{~cm}$ soil layer. The significant correlations are highlighted with bold characters.

\begin{tabular}{|c|c|c|c|c|c|c|c|c|c|c|c|c|}
\hline \multirow{2}{*}{ Parameters } & \multicolumn{2}{|c|}{ Total } & \multicolumn{4}{|c|}{ Plant available } & \multirow{2}{*}{$\begin{array}{c}\text { Exchangeable } \\
\mathrm{Na} \\
\end{array}$} & \multicolumn{3}{|c|}{ Water soluble } & \multirow{2}{*}{ pH } & \multirow{2}{*}{ DOC } \\
\hline & Mo & $\mathbf{N a}$ & $\mathbf{C u}$ & Mo & $\mathbf{N a}$ & $\mathbf{P b}$ & & $\mathrm{Cr}$ & $\mathbf{C u}$ & $\mathbf{N a}$ & & \\
\hline & \multicolumn{12}{|c|}{$0-30 \mathrm{~cm}$} \\
\hline $\begin{array}{l}\text { Aerobic } \\
\text { heterotrophic } \\
\text { cell number }\end{array}$ & 0.143 & 0.188 & 0.105 & 0.230 & 0.132 & 0.132 & 0.203 & 0.130 & 0.163 & 0.546 & 0.283 & $-0.658 *$ \\
\hline $\begin{array}{l}\text { Vibrio } \\
\text { Fischeri } \\
\text { ED50 } \\
\end{array}$ & 0.213 & 0.248 & 0.080 & 0.089 & 0.307 & 0.302 & 0.287 & 0.322 & 0.328 & 0.192 & 0.121 & 0.144 \\
\hline $\begin{array}{l}\text { Sinapis alba } \\
\text { root growth } \\
\text { inhibition }\end{array}$ & $-0.914 * *$ & $-0.865 * *$ & $-0.851 * *$ & $-0.909 * *$ & $-0.883 * *$ & $-0.931 * *$ & $-0.887 * *$ & $-0.700 *$ & $-0.789 *$ & $-0.738 *$ & $-0.830 * *$ & -0.323 \\
\hline $\begin{array}{l}\text { Sinapis alba } \\
\text { shoot growth } \\
\text { inhibition }\end{array}$ & -0.434 & -0.573 & -0.416 & -0.431 & $-0.585^{*}$ & -0.538 & $-0.593 *$ & $-0.600 *$ & $-0.709 *$ & -0.412 & -0.522 & 0.038 \\
\hline \multirow[t]{2}{*}{$\begin{array}{l}\text { Folsomia } \\
\text { candida } \\
\text { mortality } \\
\end{array}$} & $0.606 *$ & $0.672 *$ & $0.636 *$ & $0.631 *$ & $0.710 *$ & $0.655^{*}$ & $0.671 *$ & 0.678* & $0.578 *$ & 0.241 & $0.593^{*}$ & $0.711 *$ \\
\hline & \multicolumn{12}{|c|}{$30-50 \mathrm{~cm}$} \\
\hline $\begin{array}{l}\text { Folsomia } \\
\text { candida } \\
\text { mortality } \\
\end{array}$ & 0.108 & -0.516 & $0.675^{*}$ & -0.308 & 0.256 & $0.620 *$ & 0.361 & -0.357 & 0.343 & $0.866 * *$ & 0.136 & $0.782 *$ \\
\hline
\end{tabular}

**Correlation is significant at the 0.01 level (2-tailed).; * Correlation is significant at the 0.05 level (2-tailed) 